\title{
MULHERES NO LAR: MACHISMO OU PODER?
}

\author{
ONDE ESTÃO OS DONOS DE CASA? AO MESMO TEMPO EM QUE \\ ENFRENTAM A JORNADA DUPLA DE TRABALHO E SE QUEIXAM DA \\ FALTA DE COLABORAÇÃO MASCULINA NAS TAREFAS DOMÉSTICAS, AS \\ MULHERES NÃO ABREM MÃO DE SEU DOMÍNIO NESSE ESPAÇO DE PODER
}

\author{
| POR MARIA ESTER DE FREITAS
}

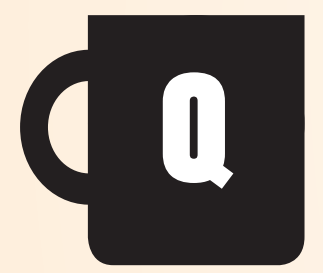

uando fui convidada a escrever um artigo para este caderno especial, busquei fugir do que já se tem abordado sobre gênero, quase transformado em sinônimo de feminino. Explorarei o tema a partir de uma perspectiva crítica, como advogada do diabo, provocativa e refletindo sobre um aspecto dificilmente discutido: por que as mulheres são donas do lar e não existem donos do lar?

Ora, se fomos competentes para sair da estaca zero e em 100 anos conquistar espaços inacessíveis ao longo da história; se temos capacidade de ocupar escolas e universidades, detendo hoje a maioria dos diplomas; se tivemos coragem de enfrentar pais, irmãos, maridos, noivos e namorados machistas e retrógrados que nos desestimulavam a ir contra a corrente; se fomos ousadas para desafiar a igreja e outras instituições sociais em relação ao domínio de nosso corpo, conquistando o direito de decidir sobre a reprodução e o prazer sexual; se somos detentoras reconhecidas de habilidades comunicativas e de negociação, valorizadas em ambientes de trabalho extremamente competitivos e agressivos; então como explicar a aparente incompetência em conseguir que nossos parceiros sejam também donos de casa e assumam a parte que lhes cabe neste minifúndio?

\section{PROCURAM-SE DONOS DO LAR}

Considerando as reclamações das mulheres a respeito da sua sobrecarga devido aos cuidados do lar, tanto em sociedades ricas quanto pobres ou arremediadas, parece-nos que este insucesso é um fenômeno ocidental. Se isto é verdade, quais seriam as razões subjacentes ao retumbante fracasso das mulheres em negociar com os seus homens o compartilhamento do trabalho doméstico? Pensamos em três caricaturas de resposta:

a) Machismo fortemente aconcorado na sociedade e, portanto, também presente e assumido na relação do casal, o qual se acostumou que as coisas são assim mesmo: a mulher deve ser a rainha do lar, independente de ter ou não uma atividade profissional externa. Quando não trabalha fora porque o marido "não deixou", ela pode jogar isso na mesa de vez em quando, ao mesmo tempo em que padece do medo dele dizer "pois então, vá" e ela não ser capaz de dar conta do recado por estar desatualizada, não ter jogo de cintura suficiente para segurar as pressões, por suas competências duvidosas ou simplesmente porque ninguém ali está falando sério; é só um jogo. Neste caso, ela desempenhará com resignação (e uma reclamaçãozinha de vez em quando, para salvar as aparências) e muito 


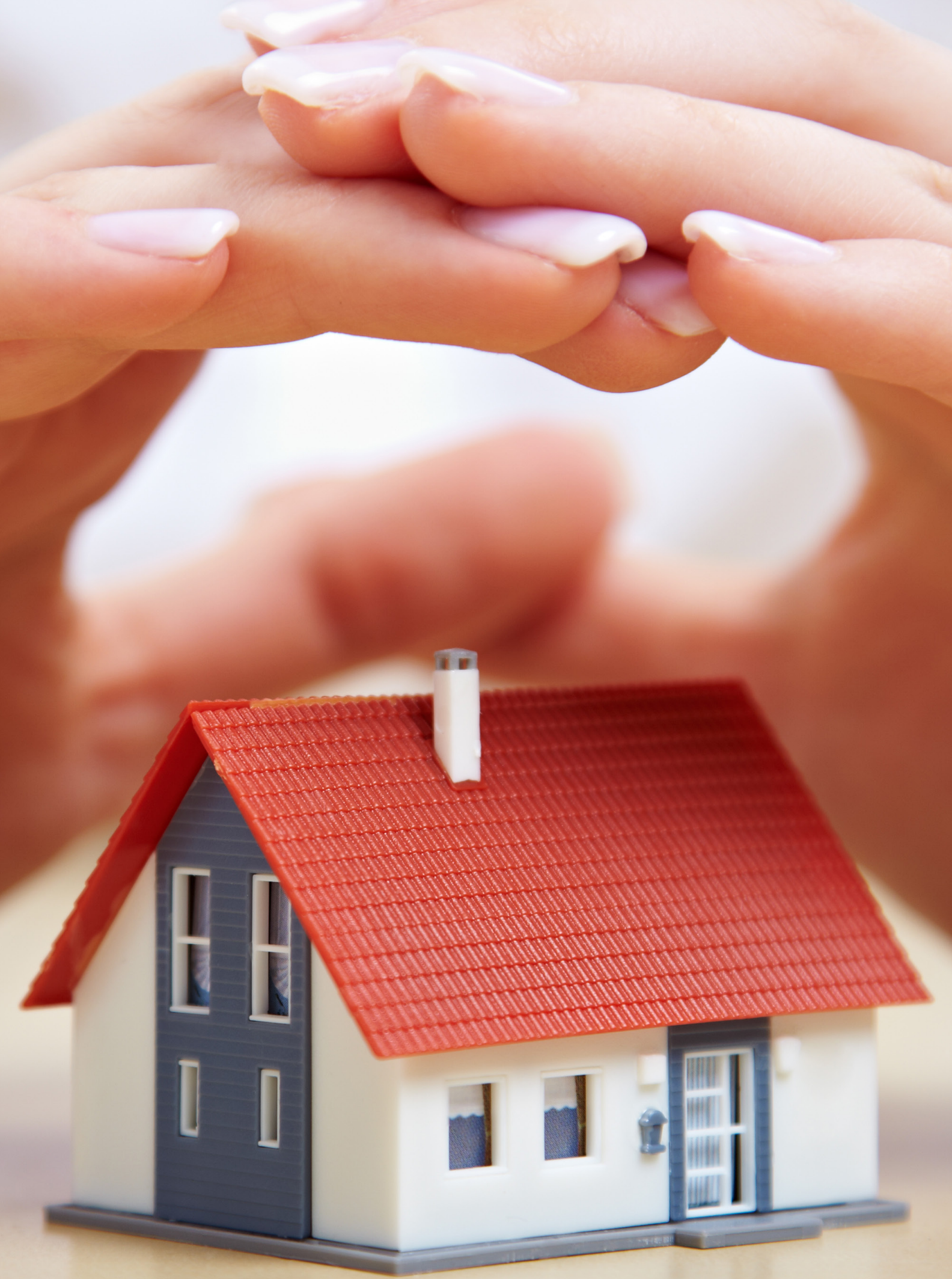


amor os seus desdobramentos como mulher maravilha. Invejará e desqualificará as "carreiristas". Aqui, as olheiras serão os troféus.

b) Conveniência mútua para não gerar conflitos: o homem fica na sua quando chega em casa, pega uma cerveja na geladeira e vai assistir ao noticiário e ao futebol enquanto a mulher troca o tailleur pelo avental, checa se os filhos estão enfiados em seus quartos, corre para a cozinha, prepara a refeição, põe a mesa, esquenta o que foi preparado antes e chama a família para ser nutrida. Depois, confere se a criançada fez as tarefas da escola, arruma a mesa, limpa a cozinha, dá conta das roupas sujas da família, tira o lixo, faz a lista do que precisa ser providenciado, toma um banho e pega o seu laptop para preparar a reunião do dia seguinte.

c) Manter o poder seguro em um espaço já legitimado, para o qual a mulher foi preparada pela sociedade, durante séculos, e assumir como se isso não fosse cultura, mas parte de seus genes: o universo doméstico está quase exclusivamente sob o comando da mulher, mesmo que ela trabalhe fora e tenha uma jornada pesada. Isso inclui a sua voz decisiva: sobre filhos, a escola, o que se come em casa, com o que se brinca, que programas de TV podem assistir, hora de dormir, conhecer amigos dos filhos e seus pais, que roupas vestem, qual o valor da mesada, onde serão as férias, a programação dos fins de semana, o cuidado com os idosos da família, os convidados das festas, etc. Muitos homens tentam furar esse bloqueio, mas são totalmente desqualificados e, desajeitados, vão fazer errado e tudo terá que ser refeito por ela. Além disso, demoram demais e só fazem uma coisa de cada vez. Moral: o homem, que não é bobo, recolhe-se na sua pseudo-incompetência e vai curtir a cerveja e o futebol tranquilo, enquanto a mulher se mata estoicamente e tem mais uma justificativa para continuar sendo responsável por tudo. Ele pode até dar uma "mãozinha" quando ela deixar que o homem a "ajude".

\section{ELAS NÃO ABREM MÃO DO PODER}

Sei que os três retratos citados estão desfocados e não dão conta por inteiro da pergunta proposta, mas parece ser consenso que o repertório feminino é muito mais amplo do que o masculino atualmente, visto que a mulher mantém o domínio do mundo da casa ou da vida, e agora tem conhecimentos, e também o domínio, do mundo das coisas ou do sistema, como diria Habermas. De um lado, disputam os espaços de

\section{Machismo, fuga de conflitose conservacão do poder feminino são as razões para o fracasso da mulher em negociar o trabalho doméstico com o homem}

poder no mundo externo, causando um verdadeiro rebuliço no mercado antes exclusivamente masculino; de outro, criam sérias dificuldades à inclusão do homem no lar, de forma que ele continue incompetente neste espaço de poder.

Estariam as mulheres exercendo o seu preconceito contra os homens no mundo da casa, excluindo-os, mesmo quando dizem que querem que eles contribuam com esse trabalho? Não estariam reminiscências atávicas agindo em ambos os lados, fazendo os homens evitarem e as mulheres protegerem a esfera doméstica como um lugar exclusivo seu? De alguma forma, parece que nós, mulheres, criamos uma armadilha para nós mesmas: queremos que nossos homens colaborem conosco, mas que não expandam demais o seu domínio a ponto de aspirarem a ser donos da casa. Assim, vamos garantindo essa ambiguidade reclamando e, ao mesmo tempo, reproduzindo nos filhos o modelo anterior.

\section{QUEBRANDO PARADIGMAS}

Não estou dizendo que essas posições sejam de natureza consciente e conspiratória entre as mulheres, mas é evidente que a reivindicação de maior participação do público masculino nas tarefas da casa não bate com a preparação para isso, afinal somos nós as primeiras responsáveis pela socialização dos filhos. A educação de berço continua tendo papel chave, ainda que o contato institucional (creche, escola) comece hoje bem mais cedo. Quando escolhemos os brinquedos, estamos dando mais que uma buginganga 


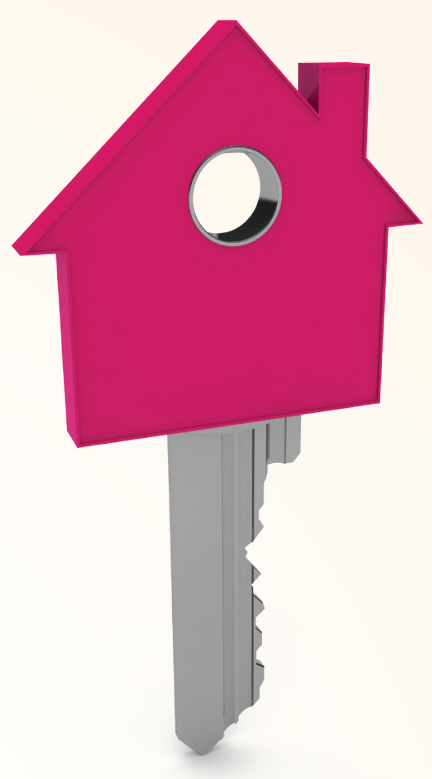

para se divertirem, estamos transmitindo mensagens que consolidam e estruturam o pensamento. Por que não se pode dar carrinhos para meninas e panelas ou bonecas para os meninos? Afinal, nós dirigimos carros, nossos maridos fazem churrascos e miojos, trocam fraldas. Mas os brinquedos continuam lá segregando, condicionando, direcionando, estabelecendo, estereotipando.

Escolhemos as escolas dos filhos, mas o que sabemos mesmo sobre elas? O que podem fazer para diminuir preconceitos? Que tal incentivarem ambos os sexos a aproveitar as oportunidades de todas as disciplinas? Afinal, elas não exigem atributos exclusivamente masculinos ou femininos, senão inteligência e persistência. Conteúdos sobre os papéis exercidos pelos gêneros podem ser usados para debates e novas aprendizagens sobre sociedade, cidadania, justiça, preconceito, racismo e discriminação.

Ora, sabemos que os preconceitos não são eventos produzidos pela diferença entre sexos, mas por um ordenamento social. Portanto, a mudança de mentalidades e comportamentos exige um esforço individual e coletivo em direção ao que a sociedade imagina ser o seu melhor; assim ela evolui ou regride.

Durante os últimos 100 anos, as sociedades se humanizaram mais porque as mulheres mudaram, alterando a paisagem social, política, cultural, religiosa, familiar e sexual. Felizmente os homens também mudaram: podem chorar sem sentir que perderão a virilidade; assumem que são pais corujas e mostram as fotos dos rebentos a todos; querem

\section{De um lado elas disputam os espacos de poder no ambiente externo, de outro, criam dificuldades à inclusão do homem nas tarefas do lar}

e precisam que suas companheiras trabalhem fora do lar; aprendem a trocar fraldas, dar mamadeiras e cantar cantigas de ninar; desenvolvem competências culinárias que variam de feitos gastronômicos a ovo frito; sabem o que é e respeitam a TPM; engolem que as mulheres no trânsito causam menos acidentes e são premiadas pelas seguradoras; entendem e apoiam que elas estudem mais, progridam na carreira e tenham uma vida familiar, profissional e sexual plena. Se ambos os sexos aprenderam isso tudo, onde as coisas emperram? A vida profissional da mulher "tirou" a sua histórica dedicação exclusiva ao lar e muitos maridos ainda consideram o trabalho doméstico degradante demais para brigarem por ele. Mulheres modernas incomodam porque querem saber de tudo e se metem em todas as conversas; maridos e mulheres sabem que infidelidade não será mais tratada impunemente. Elas criaram asas, têm dinheiro próprio e, quando não discutem mais a relação, procuram um advogado para informar o divórcio.

Muitos homens não sabem como se colocar frente a estas novas mulheres, porém não querem mais pagar o preço pela falocracia histórica, buscando ficar em paz consigo mesmos e se reconciliar com a emancipação feminina. Quem sabe chegou a hora das mulheres se mostrarem menos defensivas e prepararem os seus companheiros para assumir a outra face da vida: a produção doméstica.

MARIA ESTER DE FREITAS > Professora da FGV-EAESP > ester.freitas@fav.br 